\title{
Material Transfer Agreements on Teff and Vernonia - Ethiopian Plant Genetic Resources
}

\author{
Abeba Tadesse Gebreselassie (Corresponding Author) \\ Department of Business Law, ASB, Aarhus University \\ Hermodsvej 22, 8230 Abyhoj, Arhus, Denmark \\ Tel: 45-8948-6861 \\ E-mail: abge@asb.dk OR abebatadesse@gmail.com
}

\begin{abstract}
Humans require plant resources to satisfy their basic needs for clothing, food, medicines, shelter, and so on. In order to conserve and sustain the use of these resources, the Convention on Biological Diversity (CBD), and the FAO International Treaty on Plant Genetic Resources for Food and Agriculture have been adopted as international measures, and the African Union's Model Law has been adopted as a regional measure, to provide legal frameworks for how these resources are to be accessed and how the benefits obtained from their use should be allocated. As a signatory to the CBD, Ethiopia issued its Access and Benefit Sharing law in 2006. Ethiopia has signed material transfer agreements on teff (gluten free and nutritious) and vernonia (the green chemical plant of the $21^{\text {st }}$ Century) with two European companies. This article discusses and seeks to interpret the terms of the agreements on teff and vernonia. Furthermore, it analyzes the implications of the terms of the agreements for the realization of the objectives of the CBD (e.g. access, benefit sharing and conservation).
\end{abstract}

Keywords: Access, Benefit sharing, Ethiopia, Plant genetic resources, Teff, Vernonia

\section{Introduction}

\subsection{Overview: Laws}

The international community gave expression to the need to ensure the conservation and sustainable use of plant genetic resources with the adoption of the Convention on Biological Diversity (CBD), the FAO International Treaty on Plant Genetic Resources for Food and Agriculture (FAO Treaty) and the Bonn Guidelines on Access to Genetic Resources and Fair and Equitable Sharing of the Benefits Arising from their Utilization (the Bonn Guidelines) (Note 1).

Conservation, sustainable use, appropriate access, and fair and equitable sharing of the benefits arising out of the use of genetic resources are the objectives of both the CBD and the FAO Treaty (Note 2). The CBD defines sustainable use as 'the use of components of biological diversity in a way and at a rate that does not lead to the long-term decline of biological diversity, thereby maintaining its potential to meet the needs and aspirations of present and future generations' (Note 3).

The FAO Treaty and the CBD provide a comprehensive framework for the conservation and sustainable use of plant genetic resources. Both legal instruments require the Contracting Parties to take general measures, including but not limited to the enhancement of the application of traditional cultural practices that are compatible with the sustainable use of plant genetic resources (Note 4).

The rights and obligations derived from this framework of the FAO Treaty and the CBD are addressed to the Contracting Parties, so that the obligations, strategies, policies and measures are to be implemented at national level. The Contracting Parties have to enact laws and adopt policies accordingly. The details of the measures taken by different countries may differ, depending on the need, capacity and choice of each country. Ethiopia is a party to the $\mathrm{CBD}$ and to the FAO Treaty. In order to fulfil its obligations under these treaties, Ethiopia has adopted the National Policy on Biodiversity Conservation and Research. Furthermore, in 2006, Ethiopia enacted its Access and Benefit Sharing law (ABS law), officially entitled the 'Access to Genetic Resources and Community Knowledge, and Community Rights proclamation No 482/2006’ (Note 5).

Ethiopia's National Policy on Biodiversity Conservation and Research states that, 'the government of the Federal Democratic Republic of Ethiopia shall take the necessary steps to discharge its obligations under the treaties concerning the protection, conservation or utilization of biological resources' (Note 6). Ethiopia enacted its ABS law in fulfilment of its obligations as a Contracting Party to the CBD. The objective of the legislation is 'to ensure that the country and its communities obtain fair and equitable share from the benefits arising out of the use of genetic resources so as to promote the conservation and sustainable utilization of the country's biodiversity resources.' This is the very same goal as that found in the CBD. 
The Bonn Guidelines and the Ethiopian ABS law are aimed at fulfilling the objective of the 'fair and equitable sharing of the benefits arising out of the utilization of genetic resources', as set out in the CBD. The FAO Treaty, which is aimed at the sustainability of plant genetic resources, is only applicable to plant genetic resources for food and agriculture. The FAO Treaty is also considered to be a measure implementing the CBD.

In summary, the objectives of the CBD, the FAO Treaty and the Ethiopian ABS law are to ensure 'sustainable use of plant genetic resources', 'conservation of plant genetic resources' and 'access to and benefit sharing from the utilization of plant genetic resources'.

\subsection{Meaning of plant genetic resources}

Understanding what a 'plant genetic resource' means is important not only for understanding the importance of the conservation of these resources, but also for understanding the different implications of material transfer agreements. The CBD defines genetic resources as 'genetic material of actual or potential value' (emphasis added), and genetic material is defined as 'any material of plant, animal, microbial or other origin containing functional units of heredity' (emphasis added) (Note 7). Despite the fact that the meaning of 'plant genetic resource' depends on the meaning of the two key terms ('functional units of heredity' and 'actual or potential value'), the CBD does not define these two key terms. The opinion of technical experts is that 'functional units of heredity' refers to DNA (deoxyribonucleic acid) and RNA (ribonucleic acid) (Note 8).

The Ethiopian ABS law defines a plant genetic resource as 'any genetic material of biological resources containing genetic information having actual or potential value for humanity and it includes derivatives' (emphasis added) (Note 9). A 'derivative' is a product extracted or developed from biological resources, and this may include products such as plant varieties, oils, resins, gums, chemicals and proteins (Note 10). However, the CBD does not include derivatives. For example, vernonia is a plant genetic resource, and oil derived from vernonia is a biological product. Oil does not contain RNA and DNA and thus it cannot be considered a plant genetic resource (Note 11). Despite this, the ABS law considers derivatives of plant genetic resources, such as oil derived from vernonia, to be a genetic resource. Does this mean that the ABS law regulates the export of vernonia oil rather than international trade law? The answer may be in the affirmative, as vernonia oil is within the scope of 'plant genetic resources' according to the ABS law.

\subsection{Financial resources for the conservation of plant genetic resources}

Countries are dependent on each other for plant genetic resources. No country is self-sufficient in plant genetic resources. However, there is an imbalance in the distribution of plant genetic resources in the world. Developing countries (the South) are home to many plant genetic resources and they are expected to ensure the conservation of the plant genetic resources in their territories. However, ensuring the conservation of these resources is not costless. As Roger A. Sedjo has said: 'If preservation were costless, then all genetic resources would be preserved' (Note 12). Even if developed countries had been able to obtain benefits from the exploitation of plant genetic resources prior to the adoption of the CBD, there was no clear framework to support providing countries in negotiating the sharing of benefits with user countries. Therefore, 'developing countries felt resentful to invest in the sustainability of plant genetic resources - due to absence of benefit sharing from the side of the developed countries' (Note 13).

The Brundtland Commission Report on sustainable development required states to integrate conservation into their planning of development activities. The Report also called on developed countries to support and assist developing countries in matters of environmental protection and sustainable development (Note 14). Requiring the Contracting Parties to provide sound measures, policies and strategies for conservation is not enough to ensure the conservation of plant genetic resources. Except for Australia, most of the countries with natural plant genetic resources are too poor to invest in the conservation and sustainable use of their plant genetic resources.

Given the lack of financial resources, the CBD and the FAO Treaty have devised two mechanisms aimed at establishing or strengthening the financial capabilities of countries, especially developing countries, with respect to the sustainable use and conservation of plant genetic resources. The first mechanism requires developed countries to provide 'new and additional financial resources' to assist developing countries in meeting the incremental costs of implementing measures to fulfil their obligations for the sustainable protection of plant genetic resources (Note 15). To implement the first mechanism for financial and technical assistance, the FAO Treaty has established the Global Plan of Action and the CBD has provided financial resources through the Global Environmental Facility.

The second mechanism follows from the reaffirmation of the sovereign right of states to determine access to their plant genetic resources. This mechanism is aimed at strengthening states' capabilities, both financially and technologically, to protect plant genetic resources sustainably. The sovereign right of states over their natural resources is a well-accepted principle of public international law. Principle 21 of the Stockholm Declaration of the UN Conference on the Human Environment and Principle 2 of the Rio Declaration on Environment and Development reaffirmed the sovereign right of states over their natural resources, and this was restated in Article 3 of the CBD (Note 16). 
The CBD has reaffirmed states' sovereign rights over their plant genetic resources, stating that: 'the authority to determine access to genetic resources rests with the national governments and is subject to national legislation' (Note 17). Thus, following the CBD, countries have enacted laws laying down who decides on access permits. For example, Article 5(1) of the ABS law states: 'the ownership of genetic resources shall be vested in the state and the Ethiopian people.' Thus, access to Ethiopian plant genetic resources has to be negotiated with the Ethiopian government. With the clear reaffirmation of states' sovereign right to decide on access to their plant genetic resources, Ethiopia, for example, has negotiated two access agreements following the adoption the CBD.

\section{Background to the Material Transfer Agreements}

\subsection{Teff}

Teff belongs to the genus Eragrostis, which is one of a large family of wild grasses. It originated in and was domesticated in Ethiopia and is grown as a cereal. Teff is an important cereal at the national level. Ethiopia is the only country that is a source of genetic diversity for teff.

Teff has as much or even more food value than major grains such as wheat, barley and maize (Note 18). Moreover, grains such as wheat, rye, barley, and derivatives of these grains contain gluten. Gluten intolerance (coeliac disease or gluten sensitivity) is 'a lifelong autoimmune disorder in which a person's body cannot tolerate a group of grain proteins known as gluten' (Note 19). Since teff is gluten free, it can be used for the preparation of foods for gluten-intolerant individuals (Note 20).

In Ethiopia, teff grain is ground into flour and fermented for the preparation of teff-based foods (Note 21). Teff flour is the preferred grain for preparing injera, a traditional gluten-free pancake (Note 22). The traditional uses of teff flour also include the preparation of teff bread and a pudding (genfo), while teff grain is used to make local alcoholic drinks such as tella and katikala (Note 23).

More than a century ago, in 1886, long before the adoption of the CBD, the Royal Botanic Gardens at Kew, England, accessed teff. The Royal Botanic Garden then distributed teff to other botanic gardens in Australia, Africa and Asia (Note 24). Teff is currently being commercially produced for human consumption by an American company (The Teff Company) and a Dutch company (Health and Performance Food International).

The Teff Company, based in Idaho, is currently cultivating teff for human consumption and as animal fodder (Note 25). The founder of the Teff Company, Wayne Carlson, was involved in Ethiopian affairs in the 1970s. Upon his return to Idaho, he was able to plant teff successfully. There is no information, however, as to how he accessed teff plant genetic resources. This might be because, prior to the adoption of the $\mathrm{CBD}$, access to plant genetic resources was unregulated.

\subsection{Vernonia}

Vernonia (vernonia galamensis) is a tall plant with shiny black seeds that originated in Ethiopia (Note 26). Robert E. Perdue first identified vernonia near the old city of Harar in Eastern Ethiopia in December 1964. Vernonia, being an endemic tropical plant, is most suitable for dryland farming and requires drained soil and low rainfall (Note 27).

Vernonia has unique properties that make it interesting, both economically and ecologically. Vernonia oil ( $35 \%$ to $42 \%$ of the seed) contains vernolic acid ( $72 \%$ to $80 \%$ of the oil) (Note 28 ). Vernolic acid is a useful raw material for the manufacture of adhesives, varnishes, paints and coatings. Using vernolic acid for paints and coating helps to avoid photochemical pollution (Note 29).

Vernonia grows in most parts of Ethiopia. Traditionally, farmers considered it to be an indigenous weed, so they tended to eradicate it in order to free their land for other crops. Due to the increased awareness of the importance of vernonia, however, it is now considered a potential crop for inclusion in the agricultural system of the country (Note 30).

\subsection{Parties to the agreements}

In 2004, Ethiopia signed its first material transfer agreement on teff. This agreement was made between the Ethiopian government (the Institute of Biodiversity Conservation and Research and the Ethiopia Agricultural Research Organization (EARO)) and the Dutch Company, Health and Performance Food International BV (now called Soil and Crop Improvement BV) (Note 31). In 2005, the Ethiopian government (the Institute of Biodiversity Conservation and Research and EARO) and a UK company Vernique BioTech Ltd (Vernique) signed a material transfer agreement on vernonia plant genetic resources (Note 32).

In Ethiopia, the Institute of Biodiversity Conservation and Research is a national institute with the authority to grant and regulate access to genetic resources (Note 33). EARO is responsible for the coordination of national agricultural research on teff (Note 34).

EARO is not responsible for providing access to teff plant genetic resources, but because it has developed different teff varieties and is responsible for research on teff, it is a party to the agreement. The involvement of EARO seems relevant, since it is the central organization in the country with regard to teff. In contrast, no institute comparable to EARO is 
involved in the ABS agreement on vernonia. The involvement of EARO in the teff agreement also indicates the importance of teff as a plant genetic resource at national level.

Both material transfer agreements will last for ten years from the date of their conclusion (Note 35). The parties may renegotiate the agreement at the end of the ten-year period. Among other things, the agreements lay down details on access, benefit sharing, intellectual property rights, and the law governing the agreement.

\section{Terms of the agreements}

\subsection{Access}

\subsubsection{Overview}

The FAO Treaty and the CBD provide a comprehensive framework for how access is to be granted. This framework has to be implemented in the national laws of the Contracting Parties. The CBD provides a legal framework applicable to plant genetic resources in general, whereas the FAO Treaty only applies to plant genetic resources for food and agriculture (Note 36).

Because of the special nature of plant genetic resources for food and agriculture, the Contracting Parties to the FAO Treaty established the Multilateral System for facilitating access to and sharing of the benefits obtained from the exploitation of plant genetic resources for food and agriculture (Note 37). However, the scope of the Multilateral System is limited to plant genetic resources which are included in Annex I of the FAO Treaty. Therefore the FAO Treaty has to be consulted first regarding access to plant genetic resources for food and agriculture and benefit sharing. Access to and sharing benefits of plant genetic resources for food and agriculture that are not covered under the Multilateral System and other non-food plant genetic resources must be in accordance with the CBD. For example, teff and vernonia are not included in the Multilateral System of the FAO Treaty, and thus access to these resources is regulated under the $\mathrm{CBD}$ and the Ethiopian $\mathrm{ABS}$ law.

The Bonn Guidelines, which are not legally binding, identify the steps in the access and benefit sharing processes (Note 38). Thus, individual transactions on access to and the sharing of benefits obtained from the exploitation of plant genetic resources are governed by contract law and administrative procedures (Note 39).

\subsubsection{Access under the Ethiopian ABS Law}

According to its Article 4, the ABS law is applicable to access to plant genetic resources found both in situ and ex situ, and to community knowledge. The ABS law is not applicable to customary use and exchange of genetic resources and community knowledge by and among Ethiopian local communities (Article 4(2)(a)) (Note 40).

The ABS law defines access as 'the collection, acquisition, transfer or use of genetic resources and/or community knowledge' (Note 41). The definition of the term 'access' is limited to the act of accessing, and it does not qualify the person who is accessing, and thus it is possible to say that the definition of 'access' shows that the scope of application of the ABS law is not limited to access to plant genetic resources and community knowledge by foreigners.

Two requirements have to be fulfilled for a given access to plant genetic resources to fall outside the scope of the ABS law. First, the access has to be for customary use and exchange, and second, such access has to be by and between Ethiopians. Thus, in specific circumstances the non-applicability of the law to access is clear. For example, exchange of teff plant genetic resources between Ethiopian farmers can be considered as access for customary use by and between Ethiopians. Whereas, if an Ethiopian company wants to use vernonia for the production of vernonia oil, the use may not be considered customary use and thus even a domestic company may be required to comply with the access and benefit sharing requirements of the ABS law. This may be supported by the fact that vernonia does not have customary use in Ethiopia as it is considered by Ethiopian farmers to be an indigenous weed.

The ABS law is also not applicable to the sale of products of biological resources for direct consumption which does not involve the use of the genetic resources as such (Note 42). 'Direct consumption' refers to the situation where, for example, a person buys coffee beans to use directly, and not to plant them. However, if the person takes the coffee beans and plants them, this will not be 'direct use of plant genetic resources.'

\subsubsection{Prior informed consent and facilitated access}

National authorities determine access, and it is a requirement that access is subject to prior informed consent. Prior informed consent is the first step when a user company or country initiates negotiations with a providing country. Among other things, prior informed consent may include specifying the intended use of the plant genetic resource and the expected results (Note 43).

According to the Bonn Guidelines, which emphasize the importance of prior informed consent, under the system of the CBD the Contracting Parties are required to 'control' users of genetic resources under their jurisdiction; in other words, the providing country must take measures to prevent the use of plant genetic resources obtained without prior informed consent (Note 44). 
It follows from the Bonn Guidelines that states are required to facilitate access to plant genetic resources. Access has to be facilitated at minimum cost. Any restriction on access should be based on legal grounds. For example, the ABS law has listed some conditions for the denial of access, such as the intention of the user company to use the genetic resource for a purpose which is contrary to the national laws of Ethiopia or of international treaties to which Ethiopia is a party. There are also conditions related to the environment, such as when the access may risk cause harm to an ecosystem.

However, the conditions for denial of access under the ABS law lack clarity. For example, it is not clear when the use of a plant genetic resource is contrary to international treaties to which Ethiopia is party. As the CBD requires parties to avoid arbitrary restrictions that are contrary to its objectives, the Ethiopian authorities must be careful when applying the conditions for denial of access.

Without facilitated access, the exploitation of plant genetic resources may not be enhanced, and failure to facilitate access may result in poor exploitation of plant genetic resources ('the tragedy of the anticommons') (Note 45). Access is not subject to negotiation costs when the plant genetic resource is covered by the Multilateral System of the FAO Treaty. For example, as teff is not covered by the Multilateral System, Health and Performance Food International obtained access to twelve teff varieties by negotiating with the Ethiopian government (Note 46).

\subsubsection{Access and specification of use}

As mentioned before, plant genetic resources have both actual and potential values. Such values can be used for 'taxonomy, collection, research, and commercialization' (Note 47). It is on the basis of these values and uses that a providing country and a user country (or company) agree on terms, including the types of uses and limitations on the possible uses of the material (Note 48). Access under the Multilateral System of the FAO Treaty is limited to the purpose of exploitation and conservation for research, breeding, and training for food and agriculture; this excludes non-food/feed industries (Note 49).

Users are required to use plant genetic resources in a manner that is consistent with the agreed purposes. Any change of use, even if the use is unforeseen, requires a new application to be made for prior informed consent and agreed terms (Note 50). According to the Bonn Guidelines, states may monitor whether the use of plant genetic resources complies with the terms of access and benefit sharing.

Health and Performance Food International can 'use the genetic resource of teff only for the purpose of developing non-traditional teff-based food and beverage products that are listed in Annex 3 to this agreement' (Note 51). The lists of products in Annex 3 of the agreement include teff flour (gluten free flour, which can also be premixed, and a bread mix with teff) and seeds (which includes gluten-free beverages such as beer and distilled drinks). The agreement prohibits the company from using teff genetic resources for any unspecified uses, including chemical and pharmaceutical uses (Note 52).

Vernique is allowed to access vernonia seed to export and use for developing and commercializing the vernonia seed oil products specified in the annex to the agreement. The annex lists 27 products and applications of vernonia seed, such as adhesives, cosmetics, pharmaceuticals, paper and wood products, lubricants, waxes and polishes. If Vernique wants to use vernonia seed for other purposes and applications not stipulated in the list of 27 products, the company must first secure the written prior informed consent of the provider (Note 53).

\subsubsection{Exclusive access and its implications}

Following the specification of the uses of teff in the material transfer agreement, the Ethiopian government is bound by two terms. The first term states that the Ethiopian government shall not grant access to teff genetic resources to any other party for the purpose of producing the products of the company listed in Annex 3 unless the Ethiopian government secures the consent of the company. The second term binds Ethiopia not to export teff seeds if the importer or anyone else wants to use teff for products listed in Annex 3 (Note 54).

Similarly, Ethiopia cannot grant access to vernonia to any other party if that party wants to use vernonia seeds for the production of the 27 products listed in Annex I. However, if the company does not start producing those products within two years of entering into the agreement, Ethiopia can grant access to vernonia to other parties for the production of the products listed in Annex I.

Since the company has exclusive access to vernonia, Ethiopia will not be able to sign an agreement with other parties. However, if the company does not begin producing the products, it will not earn benefits and Ethiopia will not obtain benefits. Thus, by including this provision, Ethiopia can put pressure on the company and enhance the possibility of gaining benefits from the use of vernonia. Alternatively, if the company does not begin commercialization of the products, then Ethiopia is free to enter an agreement with another company.

There is no similar term in the teff material transfer agreement. Since the vernonia material transfer agreement was the second agreement negotiated by Ethiopia, the inclusion of this term can be seen as an improvement over the teff agreement, which was the first agreement signed. 
The inclusion of the term 'exclusive access' however, prohibits Ethiopia from signing another agreement and allowing access to another party who wants to use vernonia for the same purpose (Annex I). If Ethiopia were free to create a second access agreement, for example with another US company, it could be an additional source of funding for investment in the conservation of plant genetic resources.

This is especially true with regard to the exclusive access term in the teff material transfer agreement, compared to the vernonia agreement under which Ethiopia can grant other parties access to vernonia if the company does not start production of vernonia products within 2 years from the date of the agreement. The additional benefit sharing could improve Ethiopia's capacity to invest in conservation and the sustainable use of plant genetic resources.

The right to determine access to plant genetic resources is important in negotiating the terms for the sharing of benefits. It is this shared benefit that will strengthen the ability of Ethiopia to invest in the sustainable protection of plant genetic resources. Thus, the right to determine access is not an end in itself; it has to be exercised so as to agree benefit sharing clauses. The exercise of such a right is possible where other opportunities exist, i.e., where there are others demanding access to teff plant genetic resources and Ethiopia is able to grant access. This means that granting a monopoly on existing uses of teff under the guise of claiming that these are new uses will have a negative effect on the enhanced exploitation of teff genetic resources by other companies.

By including exclusive access in the agreement, and by assuming that Ethiopia is the only source of these genetic resources, the company has avoided potential competition in the market for the sale of similar products. If the exclusive access is granted because the company claims to have come up with new ideas for producing the products, then it is possible to say that the exclusive access is equivalent to intellectual property protection for the company during the ten year period of exclusive access.

However, Ethiopians have long made injera from teff flour, which is gluten-free, and teff can also be used for making local drinks such as tella and katikala. Thus, questions can be raised about the exclusive access. Is the production of gluten-free teff flour a new idea that belongs to the company? Would the exclusive term have been granted if the company had asked for access without claiming that the gluten-free teff products were the company's own idea - a new idea emanating from the company?

It is the author's view that Ethiopia should be free to decide on access to its plant genetic resources for any interested parties. The fact that the country has entered into an access agreement with one company should not prevent it entering into another agreement on the same matter, i.e. teff plant genetic resources, with another company. Companies which develop new applications or uses for plant genetic resources must seek protection under the intellectual property laws of their own country or they must use other mechanisms to ensure that others will not benefit from their investment.

\section{Benefit sharing}

\subsection{General}

The fair and equitable sharing of the benefits arising from the exploitation of plant genetic resources is the third objective of the CBD and the FAO Treaty (Note 55). Sharing benefits give states the capacity and incentive for the conservation and sustainable use of plant genetic resources. In his legal writing Gulati noted that 'benefit sharing is not based on charity but as recognition for States' investment and the principle that States should not have to bear the entire burden of subsidizing global public goods necessary for human survival' (Note 56). Benefit sharing helps the implementation of the in situ conservation of plant genetic resources. Benefit sharing from the exploitation of plant genetic resources that are covered by the Multilateral System of the FAO Treaty is one benefit arising from the use, including commercial, of plant genetic resources for food and agriculture (Note 57).

The benefit sharing has to be fair and equitable, and this depends on the existence of various factors (Note 58). From the teff example, one of the factors can be the limits which an agreement imposes on the country's opportunity to agree access and benefit sharing with other parties for uses that have already been granted exclusively to another company. Parties to a material transfer agreement can agree both monetary and non-monetary benefit sharing.

\subsection{Monetary benefit sharing}

With regard to monetary benefits, Ethiopia and Health and Performance Food International agreed on a lump sum, calculated as gross net income for a number of years (1\% of the average gross net income for years 2007,2008 and 2009) and an annual payment of $30 \%$ of the profit obtained from the sale of basic and certified seeds. The term ' $\mathrm{gross}$ net income' is not clear as it has to be either gross income (income before expenses such as tax is deducted) or net income (income after expenses such as tax is deducted). The annual royalty rate in the material transfer agreement for vernonia is $5 \%$ of the net profit after tax from the commercialization of products derived from vernonia. The royalty from the sale of products is set according to the price of the product, for example $2 \%$ of the sales value of vernonia products sold at up to EUR 2,000 per ton, and $4 \%$ of the sales value of products sold at between EUR 2,001 and EUR 10,000 per ton (Note 59). 
Vernique agreed to an upfront payment of EUR 35,000 upon signing the agreement. By comparison, the teff agreement requires Health and Performance Food International to pay a sufficient sum of money in advance which is set against the amounts due to the provider. By requiring an upfront payment, Ethiopia can obtain a payment even if the company does not use the plant genetic resources. Compared to other types of benefit sharing, which are dependent on the company's income from the exploitation of the resources, an upfront payment will help the country obtain something from the agreement, while if Vernique does not produce anything, Ethiopia is free to give access permits to other companies.

\subsection{Non-Monetary Benefits}

Vernique has agreed to source at least $75 \%$ of its annual requirements for vernonia seed by producing it and/or by buying it from contract-growers or local communities in Ethiopia (Note 60). The purpose of this term is to ensure that local communities benefit from the agreement through job opportunities and developing the skills to grow vernonia. Thus, this term attracts foreign investment to the country. However, if by force majeure the company is prevented from producing vernonia seed in Ethiopia, then the company is free to produce vernonia seed in places other than Ethiopia. In order to fulfil the remaining $25 \%$ vernonia requirements of Vernique, it is stated in the agreement that the company can produce vernonia seed in Zambia and Australia. Similarly, Health and Performance Food International is required to establish teff operations such as teff farming, cleaning and milling enterprises, and bakeries in order to contribute to the local Ethiopian economy.

The Ethiopian government and Health and Performance Food International agreed to establish a Financial Resource Support for Teff (FiRST). In order to support FiRST, the company agreed to contribute $5 \%$ of its net annual profit, which cannot be less than EUR 20,000. The purpose of FiRST is to improve the living conditions of local farming communities and to develop teff businesses in Ethiopia (Note 61).

As part of the non-monetary benefits, Vernique has agreed to train local communities. The company must share research results and technologies with the provider, as long as this does not affect the commercial advantage of the company. For the implementation of this benefit sharing, the parties will agree the research results and technologies that affect the commercial advantage of the company. Similarly, under the teff agreement, Health and Performance Food International has agreed to share research results on teff with the provider and EARO. Furthermore, the company must ensure the participation of Ethiopian scientists in its research activities.

\section{Intellectual Property Rights}

\subsection{IPRs as part of non-monetary benefit sharing}

As part of the non-monetary benefits, states can negotiate the possibility of joint ownership of intellectual property rights with users of plant genetic resources (Note 62). As shown in the teff example, the Ethiopian government and Health and Performance Food International agreed to jointly own new teff varieties that are developed by the user company (Note 63).

In addition, the agreement includes the sharing of research results, knowledge and technologies developed using teff (Note 64). There is no similar term in the vernonia material transfer agreement. This may be because there is not much research on vernonia in Ethiopia. In contrast, since teff is an important cereal at the national level, EARO has been doing research on teff plant genetic resources, and many varieties have been developed by EARO.

In neither agreement is the company allowed to obtain intellectual property rights over the genetic resources or over parts of the genetic resources. Under the teff agreement, however, the company is allowed to gain plant variety rights for new varieties of teff. Under the vernonia agreement, the company can obtain intellectual property rights relating to inventions, products or applications developed using vernonia oil (Note 65). According to the definition of plant genetic resources under the ABS law, derivatives such as oil are included within the scope of plant genetic resources. Hence, vernonia oil is considered a plant genetic resource. The company is not allowed to obtain intellectual property rights on vernonia plant genetic resources such as vernonia oil. However, the company is allowed to obtain exclusive rights on products developed from vernonia oil.

\subsection{IPRs on teff and vernonia}

The European Community Plant Variety Office has issued three plant variety rights to Health and Performance Food International. The teff varieties are named ADINA, AYANA, and TESFAYA. The applications were made on 17 December 2004, and the rights were granted on 21 April 2008. The three varieties belong to the species Eragrostis tef; however, the European Community plant variety right for teff is not the first protection granted for a teff variety. In the USA the Teff Company has obtained a plant variety right for a variety named Dessie teff.

Health and Performance Food International applied for patent rights on the processing of teff flour. The application was made through the Patent Cooperation Treaty and had many designated states, including the European Patent Office, Australia, USA, the African Regional Intellectual Property Organization, and the African Intellectual Property Organization (Note 66). 
On the 10 January 2007, the European Patent Office granted a patent (EP 2004774832) for the processing of teff flour to Health and Performance Food International. The invention related to flour of Eragrostis teff and to products derived from this flour. The invention 'makes it possible to provide food products with an eating value (taste, smell, texture, structure) acceptable in the western world which can be used as a functional food.' (Note 67)

Vernique has applied for a patent through the Patent Cooperation Treaty (PCT/GB2007/000022) for the use of epoxidized compounds. The application is pending at the European Patent Office (EP 2007700327) and in Japan (JP 2008549057). The invention relates to the use of epoxidized compounds such as oils, esters and waxes, which are based on vernolic acid. These epoxidized compounds have been found to be useful for treating lesions on mammalian skin. The lesions may be caused by disease or wounds. Particularly preferred epoxidized compounds include oils extracted from vernonia galamensis seed.

\section{Implementation of material transfer agreements}

\subsection{Implementation provisions in the ABS law}

It is one of the basic preconditions for access that a company must present the Ethiopian government with a letter from the competent authority of its home state stating that the authority shall uphold and enforce the access obligations of the user company (Article 12(4) of the ABS law). The CBD requires states to monitor the implementation of material transfer agreements. The monitoring can include applications for intellectual property rights relating to the material supplied (Note 68). In addition, countries can encourage users to disclose the country of origin of plant genetic resources in their applications for intellectual property rights (Note 69). Since the Bonn Guidelines are voluntary, such monitoring depends on the initiatives taken by the home state, for example, the Netherlands in the case of Health and Performance Food International.

According to Article 12 of the ABS law, one of the preconditions for access to plant genetic resources in Ethiopia is that the company accessing the plant genetic resources must carry out the research in Ethiopia; this means that exporting genetic resources from Ethiopia is not allowed. The rule is that the user country or company must carry out the research in Ethiopia, and that the user country or company may only exceptionally export the genetic resources from Ethiopia, if carrying out the research in Ethiopia is impossible.

When a company exports genetic resources from Ethiopia, it must present a letter of assurance from the institute that hosts or sponsors the research, and the letter must provide assurance that the research institute will observe the obligations attached to the access. Even though its implementation may be unrealistic, the inclusion of such provision in the ABS law is very important. Once plant genetic resources have left their source country, it is very complicated and it may be impossible to control their dissemination. Hence, others may be able to use these resources without the permission of the source country. As a result, Ethiopia, which is the source country, may not be able to benefit in future from the exploitation of its plant genetic resources.

An example of this may be the access to teff by the American Teff Company. Although there is no evidence as to how Wayne Carlson gained access to teff from Ethiopia, it is possible that the access may have been free and unregulated. In that case, the teff left Ethiopia and there is no agreement between Wayne Carlson and the Ethiopian government that requires him to share the benefits which the Teff Company obtains from the exploitation of teff plant genetic resources. The Teff Company is currently distributing teff seed and teff flour in the USA, but the benefits are not shared with the Ethiopian government. As there is no material transfer agreement between the Teff Company and the Ethiopian government, the Teff Company is not bound by any legal prohibition of the transfer of teff genetic resources to third parties. Thus, the Teff Company is free to transfer teff genetic resources to others. Therefore, Ethiopia not only does not share in the benefits that the Teff Company is earning for itself, but it also misses out on all the potential benefits that other companies may obtain by using teff plant genetic resources accessed via the Teff Company.

Thus, allowing the export of plant genetic resources has both short term and long term implications for the source country's interests in their plant genetic resources. Even if Ethiopia's efforts to require user companies to conduct research in Ethiopia are ambitious, the problem that it is trying to solve by this means is real.

The export of plant genetic resources from Ethiopia can have the same consequences for both regulated access and unregulated access. The consequences are similar because the implementation of material transfer agreements depends on the willingness of the user companies. The terms included in the agreements, for example prohibiting the company from giving or transferring the plant genetic resources to third parties, are aimed at controlling the dissemination of the resources. These terms may be breached, however, and enforcement may not be easy. Thus, if the user company uses the genetic resources in Ethiopia, implementation problems can be avoided more easily. Requiring companies to conduct their research in Ethiopia may also help give the country a share in technological knowledge, avoid the transfer of plant genetic resources to third parties, and prevent the use of plant genetic resources by the company after the expiry of agreement. 


\subsection{Enforcement terms in the agreement}

Provision 10 of the material transfer agreement on teff lays down terms for the enforcement of the agreement. As part of the enforcement mechanism of the material transfer agreement, Health and Performance Food International is required to submit annual financial statements to the Ethiopian government. Also, whenever there is a research result that can be protected by an intellectual property right, the company must report the full details of the research result (if an application for an IP right is made) or report the research result in general terms (if an application for an IP right is not made). The providing party and the user party have agreed to hold a meeting at least once per year in Ethiopia.

Both Health and Performance Food International and Vernique must pay a penalty if they do not pay royalties in time, and under the vernonia agreement the fine will increase as any delay in paying becomes longer. Under the teff agreement, terminating the contract in the event of the non-compliance of the company on the payment of royalties is the last resort for the government of Ethiopia. Under the vernonia material transfer agreement, the company must pay EUR 50,000 to the provider if the company transfers vernonia plant genetic resources to a third party without obtaining the permission of the provider.

If a dispute arises regarding the interpretation and application of the agreement, the parties have agreed to seek a solution by negotiation. If the negotiation fails, the parties will submit the dispute to an arbitration tribunal to be established by both parties.

\section{Conclusion}

This article examines the details of the material transfer agreements that Ethiopia has entered into with European companies. It looks in particular at some of the unique or unusual terms both in the agreements and in the ABS law.

The ownership of plant genetic resources is vested in the state and the Ethiopian people, and thus access to these resources has to be negotiated with the Ethiopian government. The definition of 'plant genetic resources' in the ABS law includes not only plant verities but also oils, chemicals and proteins developed from the plant genetic resources. Thus the scope of the term 'plant genetic resource' is broader in the ABS law than in the CBD.

The teff material transfer agreement was the first for Ethiopia, and the experience gained from this negotiation improved the terms in the vernonia material transfer agreement. Compared to the teff material transfer agreement, while both agreements allow exclusive access for the companies, under the vernonia agreement it is possible for Ethiopia to grant access to other parties if Vernique does not produce the listed products within two years from the date of the agreement. Furthermore, Vernique has agreed to source at least $75 \%$ of its annual requirements for vernonia seed by producing it and /or by buying it from contract growers or local communities in Ethiopia.

Health and Performance Food International and Vernique have gained exclusive access to teff and vernonia respectively. The companies claimed they had come up with new ideas for producing products from these resources. It is the author's view that when companies come up with new ideas for producing products from plant genetic resources, instead of gaining exclusive access to these resources, the companies should have to seek some form of protection (which can be intellectual property rights) in the countries where they intend to exploit the products commercially. Thus, the providing country must be free to enter into material transfer agreements with other parties.

The sharing of benefits from the exploitation of plant genetic resources not only strengthens a state's ability to invest in conservation and sustainable use of plant genetic resources, but also provides an economic return on the state's investment in the conservation of plant genetic resources. Thus, the enforcement of material transfer agreements, so that the benefits obtained from the exploitation of these resources are in fact shared, has an immense impact on the conservation of plant genetic resources in financially poor but gene-rich countries like Ethiopia.

In order to ensure the enforcement of its material transfer agreements, Ethiopia has included strong provisions in its ABS law and in the material transfer agreements. By law, Ethiopia does not allow the export of plant genetic resources, unless carrying out the research in Ethiopia is impossible. However, once a genetic resource has left the source country, the enforcement of the terms of a material transfer agreement will depend on the willingness of the holder of the genetic resource (user company) and perhaps the states where such companies reside.

Therefore, in order to better implement the objectives of the CBD (access, benefit sharing and conservation of plant genetic resources), first access has to be negotiated, next the capacity of providing countries to negotiate material transfer agreements has to be improved, and above all the terms of the agreements have to be enforced.

\section{References}

'Access and Benefit Sharing (ABS) in Africa, cases of bioprospecting and ABS legislations in Eastern and Southern Africa', available at http://www2.gtz.de/dokumente/bib/06-0526.pdf.

Cary Fowler. (September 2004). 'Accessing genetic resources: International law establishes multilateral system', in Genetic Resources and crop Evolution, Vol. 51, No 6, pp. 609-620. 
Chetan Gulati. (2001). "The "Tragedy of the Commons" in Plant Genetic Resources: The Need for New International Regime Centred Around an International Biotechnology Patent Office', in Yale Human Rights \& Development L.J, Vol. 4, pp. 63-107.

Ethiopian National Policy on Biodiversity and Research, available at $\mathrm{http} / / / \mathrm{www}$.ibc-et.org/publications/guidelines-strategies-reports.

Feaven Workiye. (2007). 'Agreement on access to, and benefit-sharing from, Teff genetic resources', available at http://www.abs-africa.info/uploads/media/ET-EragrostisTef-IBC-FW-2007-03.ppt.

Graham Dutfield. (2005). Intellectual Property, Biogenetic Resources and Traditional Knowledge.

Kimberly A. (2003). Tessmer, Gluten for a healthy Life.

Morten Walloe Tvedt and Tomme Young, 'Beyond Access: Exploring Implementation of the Fair and Equitable Sharing Commitment in the CBD', IUCN Environmental Policy and Law Paper No 67/2, 2007.

Muriel Lightbourne. (2006). 'Assessing the Economic Implications of Different Models for Implementing the Requirement to protect Plant Varieties' - case study of Ethiopia, produced with the support of the European Commission's $6^{\text {th }}$ Framework Programme for Research as part of the project "Impacts of the IPR Rules on Sustainable Development" (IPDEV), May.

National Academy of Sciences. (1996 ). 'Teff' in Lost crops of Africa, Vol. 1 Grains, pp. 215-235.

Tesfaye Baye. (2002). 'Genotypic and phenotypic variability in Vernonia galamensis germplasm collected from eastern Ethiopia', Journal of Agriculture Science, pp. 139 and 161-168.

R.E. Perdue et al. (1989). 'Vernonia galamensis: a promising new industrial crop for the semi-arid tropics and subtropics' in New crops for food and industry.

Moore and Tymowski. (2005). 'Explanatory Guide to the International Treaty on Plant Genetic Resources for Food and Agriculture', IUCN Environmental Policy and Law Paper No 57.

Michael A. Heller and Rebecca S. Eisenberg. (1998). 'Can patents deter innovation? The Anti Commons in Biomedical Research', Science, 1 May, Vol. 280 No 5364, pp. 698-701.

Roger A. Sedjo. (April 1992). 'Property Rights, Genetic Resources, and Biotechnological Change', Journal of Law and Economics, Vol. 35, No 1, pp. 199-213.

The agreement between the Ethiopian Government (Provider) and the Dutch company, Health and Performance Food International BV (User) concerning access to and benefit sharing from Teff Genetic Resources concluded in 2004, available at http://www.abs-africa.info/uploads/media/Teff-ABS-Agreement-2004-12_01.doc.

The World Commission on Environment and Development, Our Common Future. (1987).

The Convention on Biological Diversity. (1992).

The FAO International Treaty on Plant Genetic Resources for Food and Agriculture. (2004).

The Bonn Guidelines on access to genetic resources and fair and equitable sharing of the benefits arising from their utilization. (2002).

Ethiopian Access Proclamation No 482/2006, available at http://www.ibc-et.org/abs.

The Vernique Biotech Company website: http://www.verniquebiotech.com/.

The Health and Performance Food International BV, website http://www.soilandcrop.com/ or the English version http://www.soilandcrop.com/index.php?lang=eng.

The Teff Company website: http://www.teffco.com/.

The agreement between the Ethiopian Government (Provider) and the Vernique Biotech Ltd of the UK, Agreement Access to and benefit sharing from Vernonia.

The European patent on processing of Teff flour, Patent No EP 1646287 B1 of 10 January 2007, Bulletin 2007/02.

William Payne, 'Evaluation of Teff, Lupins, Sorghum and Other New Potential Dryland Crops in Northeastern Oregon, available at http://pnwsteep.wsu.edu/directseed/conf99/dspropWP.htm .

\section{Notes}

Note 1. The CBD was adopted at the United Nations Conference on Environment and Development (UNCED) in Rio de Janeiro, Brazil, in 1992 and entered into force on 29 December 1993. The 1983 FAO International Undertaking was adopted as a non-binding conference resolution (FAO Resolution 8/83), which later became the FAO Treaty in 
November 2001 and entered into force on 29 June 2004. See also, Biber-Klemm \& Cottier, Rights to Plant Genetic Resources and Traditional Knowledge, 2006 at p. 5.

Note 2. Convention on Biological Diversity, Art. 1 and FAO Treaty Art. 1. Concerning the requirement of sustainability see CBD Art. 6(a) and see FAO Treaty Art. 6(2)(f).

Note 3. Convention on Biological Diversity, Art. 2, sixteenth paragraph.

Note 4. FAO Treaty Art. 4 and Art. 6(1). See the Convention on Biological Diversity, Art. 6 and Art. 10(c).

Note 5. Ethiopian Access Proclamation No. 482/2006, Art. 1.

Note 6. National Policy on Biodiversity and Research, Section 3(13).

Note 7. Convention on Biological Diversity, Art. 2.

Note 8. Morten Walloe Tvedt and Tomme Young, 'Beyond Access: Exploring Implementation of the Fair and Equitable Sharing Commitment in the CBD', at p. 54.

Note 9. Ethiopian Access Proclamation No. 482/2006, Art. 2(6).

Note 10. Ethiopian Access Proclamation No. 482/2006, Art. 2(3).

Note 11. Morten Walloe Tvedt and Tomme Young, 'Beyond Access: Exploring Implementation of the Fair and Equitable Sharing Commitment in the CBD', at p. 54.

Note 12. Roger A. Sedjo, 'Property Rights, Genetic Resources, and Biotechnological Change', in Journal of Law and Economics, Vol. 35, No 1, April 1992 pp. 199-213 at p. 199.

Note 13.Graham Dutfield, Intellectual Property, Biogenetic Resources and Traditional Knowledge, at p. 6.

Note 14. The World Commission on Environment and Development, Our Common Future, 1987 at p. 349.

Note 15. FAO Treaty 7(2)(a) and The Convention on Biological Diversity, Art. 20 and Art. 21.

Note 16. 'States have, in accordance with the Charter of the United Nations and the principles of international law, the sovereign right to exploit their own resources pursuant to their own environmental policies, and the responsibility to ensure that activities within their jurisdiction or control do not cause damage to the environment of other states or area beyond the limits of national jurisdiction.'

Note 17. Convention on Biological Diversity, Art. 15(1).

Note 18. National Academy of Sciences, 'Teff', in Lost crops of Africa, at p. 222.

Note 19. Kimberly A. Tessmer, Gluten for a Healthy Life, at p. 15.

Note 20. Ibid, at p. 221. Teff does not contain the gluten which wheat contains. See also, Stallknecht et al., 'Teff: Food crop for Humans and Animals', in New crops. 2 at p. 33.

Note 21. William Payne, 'Evaluation of Teff, Lupins, Sorghum and Other New Potential Dryland Crops in Northeastern Oregon, available at

http://pnwsteep.wsu.edu/directseed/conf99/dspropWP.htm.

Note 22. 'Access and Benefit Sharing (ABS) in Africa, cases of bioprospecting and ABS legislations in Eastern and Southern Africa', at p. 8, available at

http://www2.gtz.de/dokumente/bib/06-0526.pdf.

Note 23. Feaven Workiye, 'Agreement on access to, and benefit-sharing from, Teff genetic resources', 2007, available at http://www.abs-africa.info/uploads/media/ET-EragrostisTef-IBC-FW-2007-03.ppt.

Note 24. National Academy of Sciences, 'Teff', in Lost crops of Africa, at p. 230.

Note 25. http://www.teffco.com/.

Note 26. Vernonia galamensis L. ssp. Galamensis var. ethiopica (Noya), also known as 'iron weed', see Muriel Lightbourne, 'Assessing the Economic Implications of Different Models for Implementing the Requirement to protect Plant Varieties' - case study of Ethiopia, at p. 29.

Note 27. Tesfaye Baye and Sileshi Gudeta, Pest Survey of Vernonia galamensis in Ethiopia, at p. 219.

Note 28. Tesfaye Baye, 'Genotypic and phenotypic variability in Vernonia galamensis germplasm collected from eastern Ethiopia', at p. 161.

Note 29. R.E. Perdue et al., 'Vernonia galamensis: a promising new industrial crop for the semi-arid tropics and subtropics', in New crops for food and industry at p. 197. 
Note 30. Tesfaye Baye, 'Genotypic and phenotypic variability in Vernonia galamensis germplasm collected from eastern Ethiopia' at p. 161 and p. 219. Only in one part of Ethiopia (the Arsi region), it is identified as a medicinal plant (to treat an eye disease). See, Tesfaye Baye and Heiko C. Becker, 'Exploration of Vernonia galamensis in Ethiopia, and variation in fatty acid composition of seed oil', at p. 809.

Note 31. The agreement is available at http://www.abs-africa.info/uploads/media/Teff-ABS-Agreement-2004-12_01.doc, and the website of the company: http://www.soilandcrop.com/ or the English version at http://www.soilandcrop.com/index.php?lang=eng.

Note 32. http://www.verniquebiotech.com/.

Note 33. Ethiopian Access Proclamation No 482/2006, Art. 2(8).

Note 34. The Agreement on Access to and benefit sharing from teff, Preamble 3(5).

Note 35. The Agreement on Access to and benefit sharing from teff, Provision 10, and the Agreement on Access to and benefit sharing from Vernonia, Provision 9.

Note 36. The Convention on Biological Diversity, Art. 4.

Note 37. Cary Fowler, 'Accessing genetic resources: International law establishes multilateral system', Genetic Resources and Crop Evolution, Vol. 51, No 6, September 2004 pp. 609-620 at p. 612.

Note 38. The Bonn Guidelines were adopted by the Conference of the Parties to the CBD at its sixth meeting held in The Hague in April 2002.

Note 39. Moore, and Tymowski, 'Explanatory Guide to the International Treaty on Plant Genetic Resources for Food and Agriculture', IUCN Environmental Policy and Law Paper No 57, 2005 at p. 39.

Note 40. Article 4(2)(a). 'Local community' means a human population living in a distinct geographical area in Ethiopia as a custodian of a given genetic resource or creator of given community knowledge. See, Art. 2(9), Ethiopian Access Proclamation No. 482/2006.

Note 41. Ethiopian Access Proclamation No. 482/2006, Art. 2(1).

Note 42. Ethiopian Access Proclamation No. 482/2006, Art. 4(2)(b).

Note 43. Bonn Guidelines Provision 36(f \&k).

Note 44. Bonn Guidelines Provision 16.d(iii).

Note 45. The tragedy of the anticommon refers to more 'complex obstacles that arise when a user needs multiple patented inputs to create single useful products.' There is a possibility that the same situation may arise if access to plant genetic resources is made very complex and the transaction costs outweigh the benefits to be reaped from exploiting these resources. See Michael A. Heller and Rebecca S. Eisenberg, 'Can patents deter innovation? The Anti Commons in Biomedical Research', in Science, 1 May 1998, Vol. 280 No 5364, pp. 698-701 at p. 699.

Note 46. Agreement on access to and benefit sharing from Teff, Recital 2(8). For the lists of varieties, see Annex I of the Agreement.

Note 47. Bonn Guidelines Provision 42.b(e).

Note 48. Ibid. Provision 44(b).

Note 49. FAO Treaty Art. 12.3(a).

Note 50. Bonn Guidelines Provision 16.b.(iv) and Provision 34.

Note 51. Agreement on Access to and benefit sharing from Teff, Provision 3(2).

Note 52. Ibid. Provision 3(3).

Note 53. Agreement on Access to and benefit sharing from Vernonia, Provision 3(b).

Note 54. Ibid. Provision 3(4) and Provision 6(4)

Note 55. The Convention on Biological Diversity, Art. 1 and FAO Treaty Art. 13(1).

Note 56. Chetan Gulati, 'The "Tragedy of the Commons" in Plant Genetic Resources. The Need for New International Regime Centred Around an International Biotechnology Patent Office', in Yale Human Rights \& Development L.J., Vol. 4, 2001 pp. 63-107, at p. 106.

Note 57. The benefit sharing mechanism includes 'exchange of information, access to and transfer of technology, capacity building and the sharing of the benefits arising from commercialization'. See FAO Treaty Art. 13(2).

Note 58. Bonn Guidelines Provision 45. 
Note 59. Agreement on Access to and benefit sharing from Vernonia, provision 7(1).

Note 60. Agreement on Access to and benefit sharing from Vernonia, provision 7(2.c).

Note 61. Agreement on Access to and benefit sharing from Teff, Provision 7(4) and 7(5).

Note 62. Bonn Guidelines, Provision 44.

Note 63. The Teff Agreement between the Dutch company and Ethiopia, Provision 4(2).

Note 64. Ibid. Provision 7(6).

Note 65. Agreement on Access to and benefit sharing from Vernonia, Provision 4.

Note 66.The company is now named Soil and Crop Improvement BV. However, on the patent application for the processing of teff flour, the company is named as Health and Performance Food International BV.

Note 67. International Application No: PCT/NL2004/000524.

Note 68. Bonn Guidelines, Provision 55.

Note 69. Ibid. Provision 16.d(ii). 